\title{
ACÉL- ÉS SZINTETIKUS MAKRO SZÁLAK ORIENTÁCIÓJA SZÁLERÖSÍTÉSUÚ BETONBAN
}

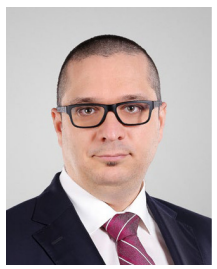

Dr. Juhász Károly Péter

A szálerösitésü beton egy rövid szálas kompozit anyag, melynek tulajdonságai nagyban függnek a mátrixban elkevert szálak orientációjától. Kiindulásként a szálak egyenletes elkeveredését és ezáltal egyenletes orientációt feltételezünk, azonban a valóságban különbözö hatások miatt ez nem teljesül. A szálak orientációjának egyenletestöl való eltérése nagy hatással lehet az anyagparaméterekre, mind kedvezö, mind kedvezötlen irányban. Jelen cikkben az irodalomban fellelhetö keverési modelleket hasonlitom össze kísérleti eredményekkel, és vizsgálom a betonozási mód, tömörités, zsaluzat hatását acél és szintetikus makro szálak orientációjára.

Kulcsszavak: szálerősítésű beton, szálak orientációja, keverési modell, anyagparaméterek

\section{BEVEZETÉS}

A betonba kevert szálak a beton számos tulajdonságát képesek javítani. Növelik a beton, mint kvázirideg anyag törési energiáját és duktilitását, ami tervezési szempontból figyelembe vehető (Gopalaratnam et al., 1991; Balaguru és Shah, 1992). A laboratóriumi anyagvizsgálatok során az úgynevezett maradó hajlító-húzó szilárdságot (residual flexural tensile strength) mérik ki, amihez a legjobban elterjed módszer a három (EN 14651, 2007) vagy négypontos (ASTM C-1609, 2019) gerendahajlítási teszt. A gerenda mérete szabványoktól és irányelvektől függ, de leginkább a 150x150 mm-es keresztmetszetü gerenda terjedt el (Juhász, 2014). A maradó szilárdság leginkább a hajlított gerenda berepedt keresztmetszetén áthaladó szálak darabszámától és azok helyzetétől függ, ami pedig további számos tényező függvénye: mint a szálak adagolása (az elkevert szálak darabszáma), a szálak geometriai mérete, a keverés homogenitása. Ennek a darabszámnak a meghatározása már a szálerősítésű beton kutatásainak a kezdetén is foglalkoztatta a kutatókat. Romualdi és Mandel (1964), majd később Naaman (1972) is adott rá képleteket. Krenchel (1975) bevezette az orientációs faktort, amivel a szálak elkeveredése jellemezhető. Tökéletes elkeveredést feltételezve ez az orientációs faktor 0,5 (Stroeven, 1978).

A szálak orientációjára sok tényező van hatással. Az orientációs tényező meghatározásával és a zsaluzat hatásával foglalkozott többek között Kameswara Rao (1979), Stroeven (1991, 1999), Soroushian és Lee (1990), Hoy (1998), Kooiman (2000), Dupont és Vandewalle (2005), Lee, Cho és Vecchio (2011), Ng, Foster és Htut (2012). A magyar szakirodalomban az acélszálak szálorientációjával Fekete (1973), Palotás (1975) és Szabó (1976) foglalkozott. A szálerősítésű beton tömörítése, vibrálása miatt a szálak orientációja szintén változik (Edgington és Hannant, 1972; Stroeven, 1979; Soroushian és Lee, 1990; Toutanji és Bayasi, 1998; Stahli, Custer és van Mier, 2008). Zerbino (Zerbino et al. 2012) acélszál erősítésű öntömörödő beton elemekben: lemezben, falban és gerendában vizsgálta az acélszálak elhelyezkedését, hasonlóan
Sarmientohoz (Sarmiento et al. 2012), aki gerendákban levö acélszálak kísérleti eredményeit vetette össze a számított értékekkel. Szintetikus szálak esetén a zsaluhatás más: míg az acélszálak a zsaluval való érintkezés során elfordulnak, addig a szintetikus szálak elhajlanak. Ezt a hatást Oh, Kim és Choi (2007) szintetikus szálerősítésü gerendák vizsgálata során nem vette figyelembe, azonban Alberti, Enfedaque és Gálvez (2017), továbbá Juhász (2018a) már ajánlást tett a szálak hajlékonyságának a modellezés során való figyelembevételére.

$\mathrm{Az}$ említett hatások miatt a szálak orientációja az egyenletestől eltér, ezért a keresztmetszeten áthaladó szálak darabszáma is változik. Gerenda tesztek kisméretü referencia felülete miatt ebből adódóan a maradó feszültségek értékének a szórása nagy lesz, ami a kiértékelésnél alacsony karakterisztikus, illetve tervezési értékekhez vezet (Bernard, 2013). A szálerősítésű beton használata során így túlzott biztonság mellett gazdaságtalan tervezéshez jutunk. A keresztmetszeten áthaladó szálak elemzése és vizsgálata így fontos téma, bár szabványok és irányelvek keveset foglalkoznak vele (Juhász, 2019).

Az olasz CNR-DT (2006) irányelv a szálak orientációjával a bevezetőben foglalkozik, felhívja a figyelmet, hogy az orientáció nagyban függ a betonozás módjától és ez nagy hatással lehet a végeredményre, az anyagparaméterek kiértékelésénél azonban nem veszi figyelembe. A RILEM TC 162 (Vandewalle et al., 2003) irányelve nem foglalkozik az orientációval. Az osztrák ÖVBB Richtlinie Faserbeton (2008) irányelv lemezszerü szerkezeti elemeknél, amennyiben vasalással együtt használják a szálak maradó feszültségi értékét $\eta=1,4$ szorzóval engedi növelni, amennyiben $b>5 h$ és $b h>1,0 \mathrm{~m}^{2}$ ( $b$ az elem szélessége, és $h$ a magassága). Külön nem említi, hogy ez a kedvező orientáció miatt van-e, de a geometriai feltételből ez valószínúsíthető. A fib Model Code (2013) 5.6.7 fejezetét szenteli az orientációnak. Itt megad egy $K$ tényezőt, mint orientációs faktort, ami általános esetben 1,0. A szálak orientációjának egyenletes eloszlástól való eltérését kísérletileg kell igazolni. Kedvező esetben ez felhasználható a számításban, kedvezőtlen esetben pedig fel kell használni a számításban. Javaslatot, módszert erre nem ad. 
A jelen cikkben elöször az irodalomban fellelhető analitikus keveredési modelleket és az azokból meghatározható orientációs faktorokat mutatjuk be. A kísérletekben különböző betonozási módszerekkel készült acél- és szintetikus makro szálerősítésü gerendák keresztmetszetén áthaladó szálak darabszáma, majd azokból a hozzá tartozó orientációs faktorokat határoztuk meg. A kísérleti és analitikus eredményeket összehasonlítjuk, majd a különböző betonozási módszerek hatását is vizsgáljuk.

\section{ANALITIKUS KEVEREDÉSI MODELLEK}

Egységnyi keresztmetszeten áthaladó szálak darabszáma meghatározható a következő képlet alapján:

$n=\theta l_{\mathrm{f}} \frac{N}{V}$,

ahol $n$ az egységnyi keresztmetszeten áthaladó szálak darabszáma $\left[\mathrm{db} / \mathrm{m}^{2}\right], l_{\mathrm{f}}$ a szál hossza $[\mathrm{m}], N$ a $V\left[\mathrm{~m}^{3}\right]$ térfogatrészben levő szálak darabszáma, $\theta$ pedig az orientációs faktor, egyenletes elkeveredés esetén 0,5. Az alábbiakban különböző kutatók orientációs faktorait mutatjuk be.

\subsection{Romualdi és Mandel modellje}

Romualdi és Mandel (1964) levezetésükben egy diszkrét szál irányát annak polárkoordinátáival adták meg, az egyenletes orientáció feltételét pedig ezen polárkoordináták egyenletes eloszlásával hozták összefüggésbe. Jól ismert tény, hogy a polárkoordináták egyenletes eloszlása mellett a szálak orientációja nem lesz egyenletes (Stroven, 1978), így a levezetett $\theta_{\mathrm{RM}}=0,405$ orientációs faktor nem az egyenletes eloszláshoz tartozik. A polárkoordináták helyett polárkoordinátával és ordinátával megadott szál esetén mindkét paraméterben egyenletes eloszlás feltételezése mellett az orientáció eloszlása egyenletes, ekkor az orientációs faktor 0,5 értéket vesz fel (Juhász, 2018a).

\subsection{Naaman modellje}

Naaman (1972) a matematikai statisztika módszerével határozta meg a szálak keresztmetszet döfésének a valószínűségét, mely alapján az orientációs faktor $\theta_{\text {Naaman }}=0,5$ lett, amely azonos Romualdi és Mandel módosított képletének eredményével (Juhász, 2018a).

\subsection{Krenchel orientációs faktora}

Krenchel abból indult ki, hogy az ideális esetben a szálak a keresztmetszetre merőlegesen helyezkednének el. Ehhez tartozó fajlagos darabszámot a következő képlettel határozta meg (Krenchel, 1975):

$n_{\mathrm{i}}=\frac{V_{\mathrm{f}}}{A_{\mathrm{f}}} A$,

ahol $n_{\mathrm{i}}$ az ideális darabszámot jelenti [db] az $A$ keresztmetszeten, $V_{\mathrm{f}}$ a szálak térfogatrésze (szálak tömege a betonban $[\mathrm{kg} /$ $\left.\mathrm{m}^{3}\right] /$ szálak térfogatsúlya $\left.\left[\mathrm{kg} / \mathrm{m}^{3}\right]\right), A_{\mathrm{f}}$ pedig egy elemi szál keresztmetszeti területe.

A valóságban azonban az elhelyezkedés nem ideális, így a valós orientációs faktor a következő képlettel határozható meg:

$\theta_{\text {Krenchel }}=\frac{n_{\mathrm{a}}}{n_{\mathrm{i}}}=n_{\mathrm{a}} \frac{A_{\mathrm{f}}}{V_{\mathrm{f}} A}$,

ahol $n_{\mathrm{a}}$ az $A$ keresztmetszeten áthaladó szálak darabszáma [db], kísérlet útján az eltört felületen történő megszámlálással meghatározva.

\subsection{Dupont és Vandewalle orien- tációs faktorai}

Dupont és Vandewalle (2005) a RILEM TC 162 (Vandewalle et al., 2000) irányelvben ajánlott gerenda keresztmetszeti méretekből indult ki, majd ezen vizsgálta a zsaluzat hatását az orientációs faktorra. A keresztmetszetet több zónára bontotta,

\section{Merev szálak (acél) Dupont és Vandewalle Juhász}

Hajlékony szálak (szintetikus) Juhász
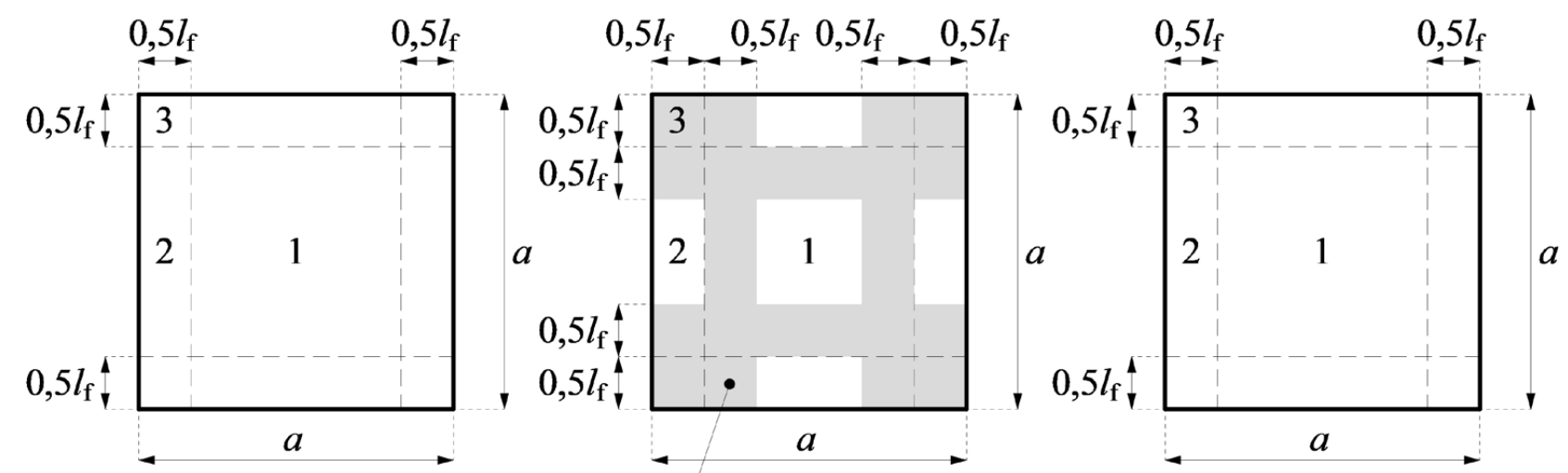

$$
\begin{array}{ll}
\theta_{1}: 0,50 \text { átmeneti részek } & \theta_{1}: 0,49-0,50 \\
\theta_{2}: 0,60 & \theta_{2}: 0,57 \\
\theta_{3}: 0,84 & \theta_{3}: 0,84
\end{array}
$$

$\theta_{1}: 0,50$

$\theta_{2}: 0,53$

$\theta_{3}:<0,84$ 
melyek: Z1 középső, zavartalan zóna; Z2 zavart zóna - egy zsaluzat hatása, szélek; illetve Z3 zavart zóna - két zsaluzat hatása, sarkok (1. ábra). Acélszálakat vizsgálva a szálakat merev szálaknak tekintette, melyek elfordulnak a zsaluzattal való érintkezéskor. Az orientációs faktorokat Juhász (2018b) módosította, melynél különbséget tett a merev (acél) és hajlékony (szintetikus) szálak között. A különböző orientációs faktorok az 1. ábrán láthatóak.

A teljes keresztmetszet orientációs faktorát az alábbi súlyozott átlagértékkel tudjuk kiszámolni:

$\theta_{\mathrm{T}}=\alpha_{1} \theta_{1}+\alpha_{2} \theta_{2}+\alpha_{3} \theta_{3}$

ahol $\theta_{\mathrm{T}}$ a teljes keresztmetszet orientációs faktora, $\theta_{1}, \theta_{2}$ és $\theta_{3}$ az 1. ábra szerinti zónák orientációs faktorai, $\alpha$ értékei pedig a következő képletek alapján számíthatóak:

$\alpha_{1}=\frac{\left(a-l_{\mathrm{f}}\right)^{2}}{a^{2}}, \quad \alpha_{2}=\frac{2 l_{\mathrm{f}}\left(a-l_{\mathrm{f}}\right)}{a^{2}}, \quad \alpha_{3}=\frac{l_{\mathrm{f}}^{2}}{a^{2}}$,

ahol $a$ a keresztmetszet szélessége és magassága az 1. ábra szerint.

A továbbiakban Juhász (2018b) analitikus modelljének orientációs faktorait használjuk.

\section{A KÍSÉRLET BEMUTATÁSA}

A kísérlet során különböző betonozási módszerekkel szálerősítésű gerendákat készítettünk acél- és szintetikus makroszálak felhasználásával. Az adagolást úgy választottuk meg, hogy mindkét típusú szálerősítésü betonban egyforma darabszámú szál legyen, így a keresztmetszeten áthaladó szálak darabszáma összehasonlítható. Az adagolás megállapításánál továbbá figyelembe vettük, hogy magasabb acélszál-adagolás esetén a szálak egymásra gyakorolt hatása miatt az orientáció módosulhat (Kang et al., 2011; Czoboly, 2016; Juhász, 2018b).

Az alkalmazott beton keverékterve az 1. táblázatban található, míg a szálak adatai a 2. táblázatban vannak összefoglalva. A beton víz/cement tényezője 0,5 , konzisztencia terülési osztály F5 volt.

1. táblázat: Beton összetétel

\begin{tabular}{|l|c|}
\hline Alkotóanyagok & Adagolás $\left(\mathrm{kg} / \mathrm{m}^{3}\right)$ \\
\hline kavics (4-8) & 629 \\
\hline homok (0-4) & 997 \\
\hline mikroszilika & 40 \\
\hline cement (CEM I 42,5 R) & 400 \\
\hline víz & 200 \\
\hline folyósító (Mapei SR1) & 3 \\
\hline
\end{tabular}

A beton konzisztenciáját folyósítóval úgy állítottuk be, hogy alkalmas legyen a mindkét betonozási módszerhez. Az elkészített gerendák mérete $150 \times 150 \times 1000 \mathrm{~mm}$ volt, amelyet kétféle betonozási módszerrel állítottunk elö. Az első módszer a szabványos betongerendáknál alkalmazott szokványos betonozás volt: a gerenda sablonja vízszintesen volt elhelyezve, és a betont felülröl öntöttük be, szakaszosan, a RILEM TC 162 (Vandewalle et al., 2000) ajánlásai alapján. A második módszernél a gerenda sablonja 45 fokban dőlt helyzetben volt és a betont úgy öntöttük bele, majd a betonozás után függőleges állapotban tároltuk a beton megszilárdulásáig
2. táblázat: A szálak adatai

\begin{tabular}{|l|c|c|}
\hline Név & Acélszál (ST) & $\begin{array}{c}\text { Szintetikus szál } \\
\text { (SY) }\end{array}$ \\
\hline Alapanyag & acél & polipropilén \\
\hline $\begin{array}{l}\text { Húzószilárdság } \\
{[\mathrm{MPa}]}\end{array}$ & 700 & 550 \\
\hline $\begin{array}{l}\text { Rugalmassági } \\
\text { modulus [GPa] }\end{array}$ & 200 & 10 \\
\hline $\begin{array}{l}\text { Szálhossz/átmérő } \\
{[\mathrm{mm} / \mathrm{mm}]}\end{array}$ & $1 / 50$ & $0.7 / 48$ \\
\hline Lehorgonyzás & kampós végü & felületi \\
\hline Szál/kg & 3181 & 35714 \\
\hline Adagolás $\left[\mathrm{kg} / \mathrm{m}^{3}\right]$ & 33.73 & 3 \\
\hline Adagolás [szál/m³ & 107346 & 107346 \\
\hline
\end{tabular}

(2. ábra). A sablonok fóliával ellátott bútorlapból készültek, az (B1) betonozási módnál az egyik hossz oldala volt nyitott, míg a (B2) betonozási módnál az egyik véglapja. A sablonok formaelválasztóval voltak bevonva a betonozás előtt. Az öntés után nem volt vibrálásos tömörítés. A kétféle öntési módszerrel két jellemző betonozási módot vizsgáltunk: a gerenda hossztengelyére merőleges, illetve az azzal párhuzamos öntési módot.

A beton megszilárdulása után a gerendákat $5 \mathrm{~cm}-e s$ szeletekre vágtuk fel a 3. ábra szerint, mely szeletek felületein áthaladó szálakat vizsgáltuk.

A felületen áthaladó szálak jól látszanak mind acél, mind szintetikus szálak esetében (4. ábra). A felületeket Dupont és Vandewalle (2005) által meghatározott zónákra osztottuk fel (1. ábra), majd az egyes zónákban található szálak darabszámát számoltuk meg. A kísérleti mátrix a 3. táblázatban látható. Acél szálerősítésü gerendák egy tipikus keresztmetszetének képe a 4. ábrán látható.

2. ábra: $A$ vizsgált betonozási módok: (B1) vízszintes, (B2) ferde

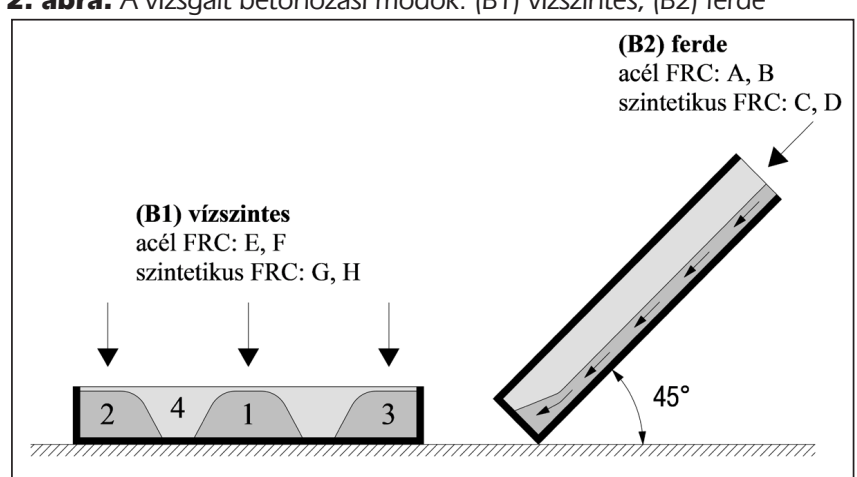

3. ábra: A kísérleti gerenda vizsgált keresztmetszetei, ahol x az adott gerenda jele

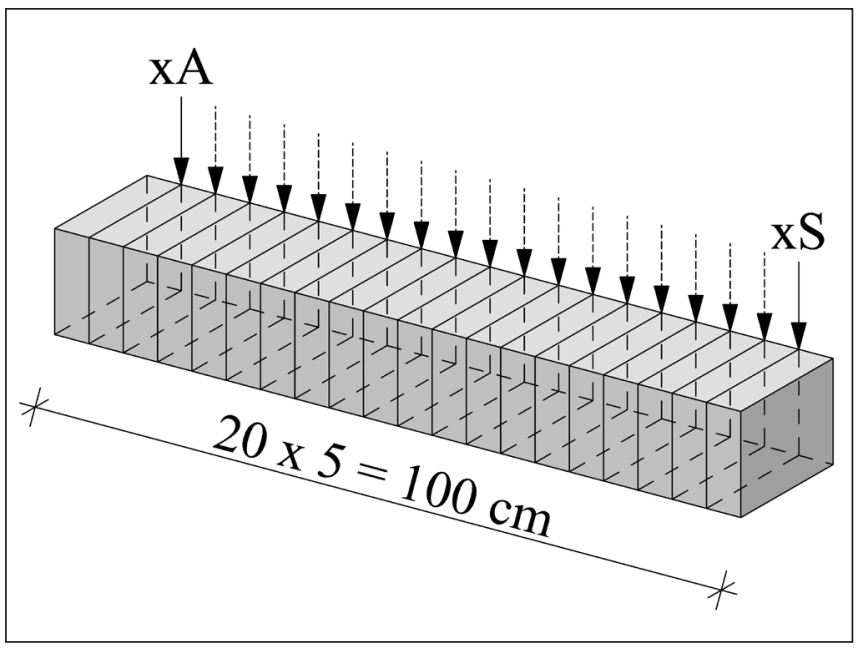


a)

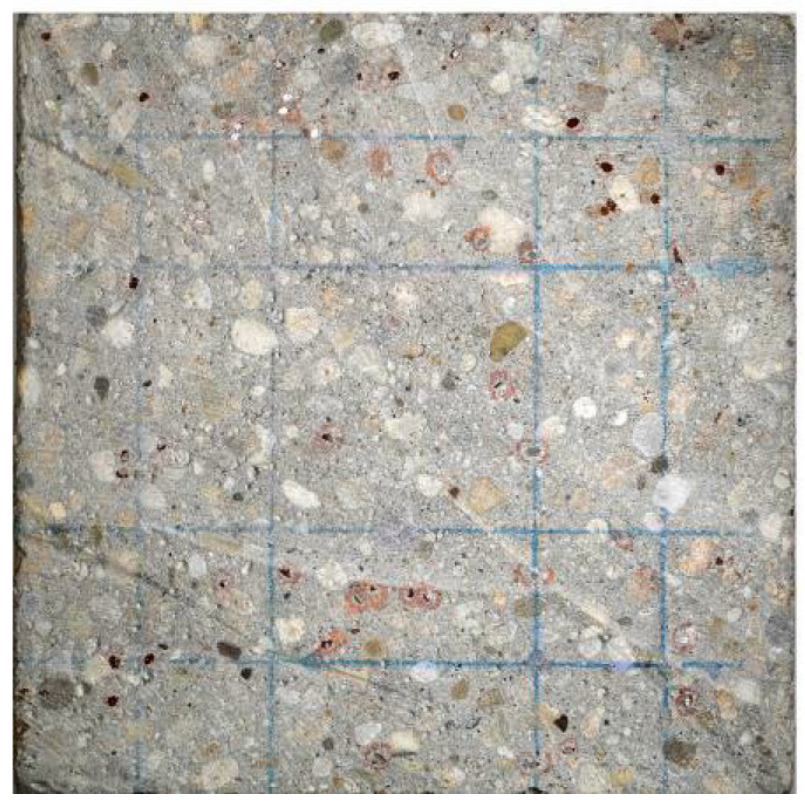

b)

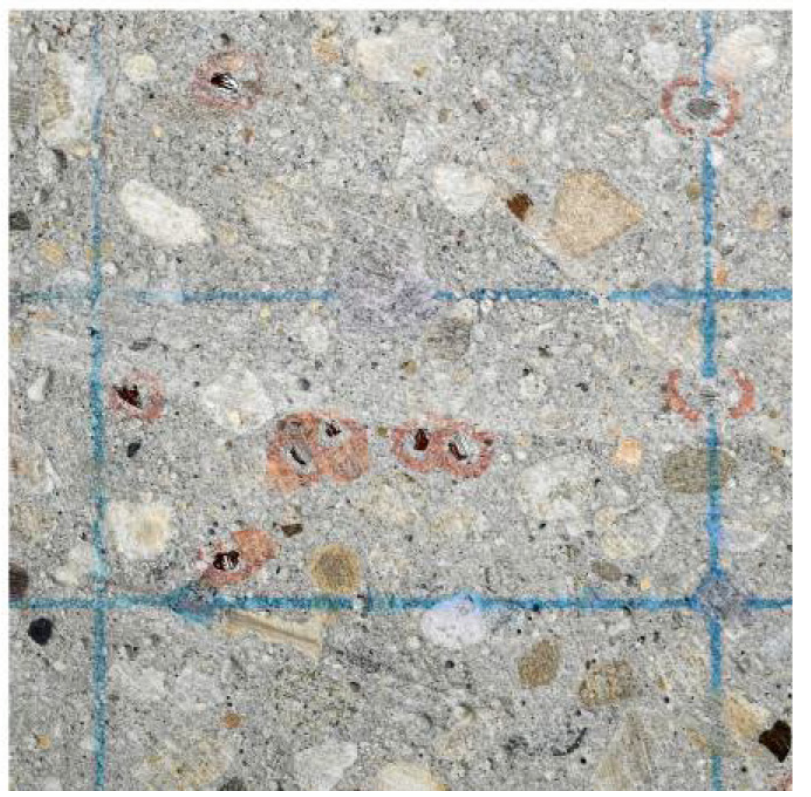

4. ábra: Acél szálerősítésű gerenda metszetei a) teljes keresztmetszet b) közeli részlet

3. táblázat: Kísérleti mátrix

\begin{tabular}{|l|l|l|l|}
\hline Száltípus & Betonozási mód & Gerenda jele & Metszetek jele \\
\hline Acél & (B1) vízszintes & E, F & EA...ES; FA...FS \\
\hline Acél & (B2) ferde & A, B & AA...AS; BA...BS \\
\hline Szintetikus & (B1) vízszintes & G, H & GA...GS; HA...HS \\
\hline Szintetikus & (B2) ferde & C, D & CA...CS; DA...DS \\
\hline
\end{tabular}

4. táblázat: Kísérleti és analitikus eredmények összehasonlítása

\begin{tabular}{|c|c|c|c|c|}
\hline \multicolumn{5}{|c|}{ Acél } \\
\hline \multicolumn{3}{|c|}{ Kísérleti eredmények középértékei } & \multicolumn{2}{|c|}{ Analitikus modell } \\
\hline zóna & $\begin{array}{c}\mathrm{db}(\mathrm{B} 1 / \mathrm{B} 2) \\
\mathrm{CV} \%(\mathrm{~B} 1 / \mathrm{B} 2)\end{array}$ & $\theta$ (B1/B2/átlag) & $\theta$ & eltérés (B1/B2/átlag) \\
\hline $\mathrm{Z} 1$ & $\begin{array}{c}33,53 \text { / 24,84 } \\
46,2 \text { / 44,8 }\end{array}$ & $0,625 / 0,463 / 0,544$ & $0,49-0,50$ & $-20 \% /+8 \% /-8 \%$ \\
\hline $\mathrm{Z} 2$ & $\begin{array}{c}31,89 / 18,62 \\
31,9 / 44,6\end{array}$ & $0,594 / 0,347 / 0,471$ & 0,57 & $-4 \% /+64 \% /+20 \%$ \\
\hline $\mathrm{Z3}$ & $\begin{array}{l}5,91 / 3,41 \\
45,4 / 56,7\end{array}$ & $0,440 / 0,254 / 0,347$ & 0,84 & $+90 \% /+330 \% /+240 \%$ \\
\hline Teljes & $\begin{array}{c}71,32 \text { / 46,86 } \\
32,4 \text { / } 35,3\end{array}$ & $0,591 / 0,388 / 0,489$ & 0,57 & $-3 \% /+46 \% /+16 \%$ \\
\hline \multicolumn{5}{|c|}{ Szintetikus } \\
\hline \multicolumn{3}{|c|}{ Kísérleti eredmények középértékei } & \multicolumn{2}{|c|}{ Analitikus modell } \\
\hline zóna & $\begin{array}{c}\mathrm{db}(\mathrm{B} 1 / \mathrm{B} 2) \\
\mathrm{CV} \%(\mathrm{~B} 1 / \mathrm{B} 2)\end{array}$ & $\theta$ (B1/B2/átlag) & $\theta$ & eltérés (B1/B2/átlag) \\
\hline $\mathrm{Z} 1$ & $\begin{array}{c}37,16 / 16,66 \\
24,1 / 43,3\end{array}$ & $0,693 / 0,311 / 0,502$ & 0,50 & $-27 \% /+60 \% / 0 \%$ \\
\hline $\mathrm{Z} 2$ & $\begin{array}{c}32,67 \text { / 23,92 } \\
19,1 / 25,4\end{array}$ & $0,648 / 0,474 / 0,561$ & 0,53 & $-18 \% /+11 \% /-5 \%$ \\
\hline $\mathrm{Z3}$ & $\begin{array}{l}8,00 / 6,26 \\
52,1 / 38,5\end{array}$ & $0,674 / 0,528 / 0,601$ & $<0,84$ & $+24 \% /+59 \% /+39 \%$ \\
\hline Teljes & $\begin{array}{c}77,83 \text { / 46,84 } \\
14,8 \text { / } 24,2\end{array}$ & $0,671 / 0,404 / 0,538$ & 0,55 & $-18 \% /+36 \% /+2 \%$ \\
\hline
\end{tabular}



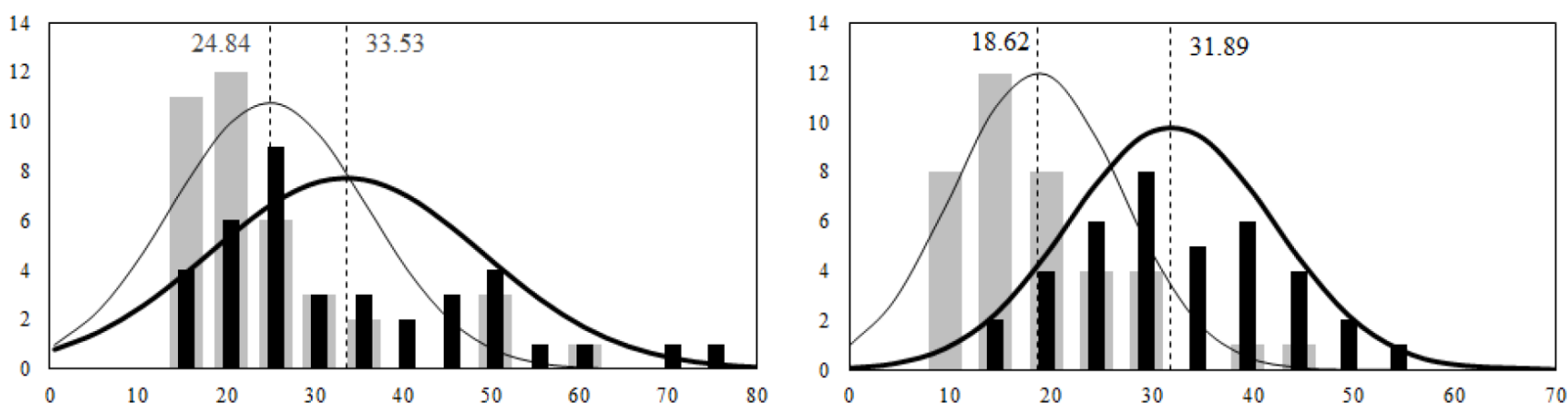

Z3 zóna - sarok (acél FRC)

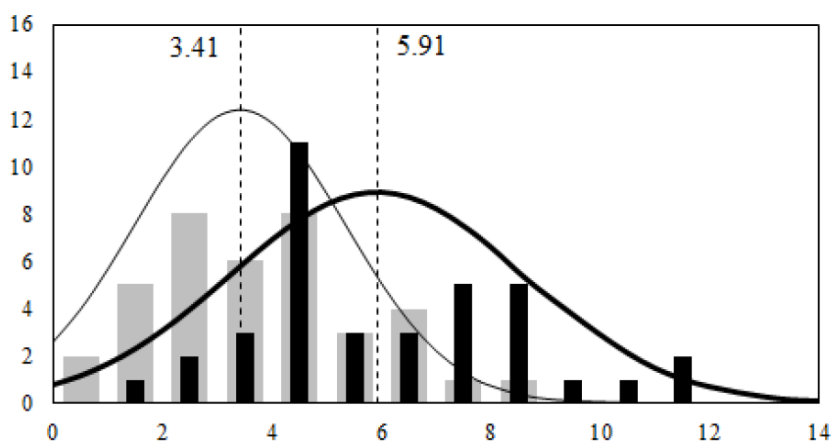

Teljes keresztmetszet (acél FRC)

Z1 zóna (szintetikus FRC)

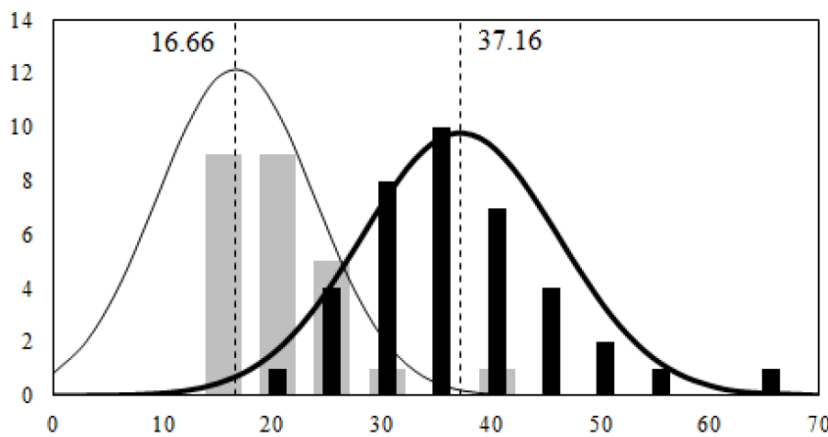

Z2 zóna - szél (szintetikus FRC)

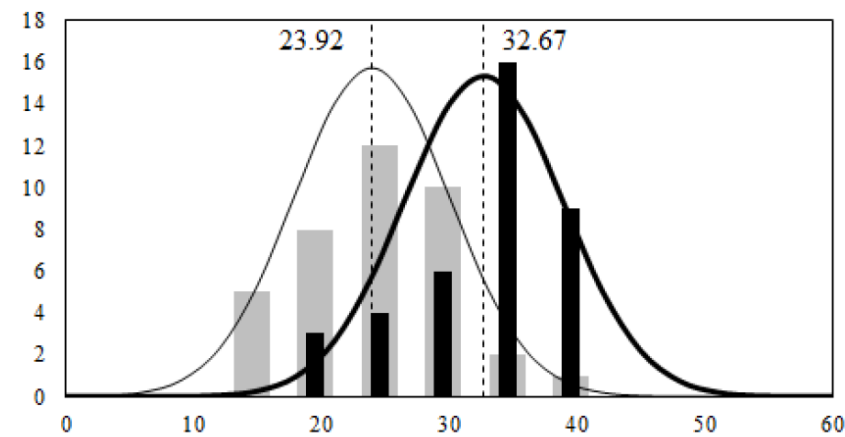

Z3 zóna - sarok (szintetikus FRC)

Teljes keresztmetszet (szintetikus FRC)
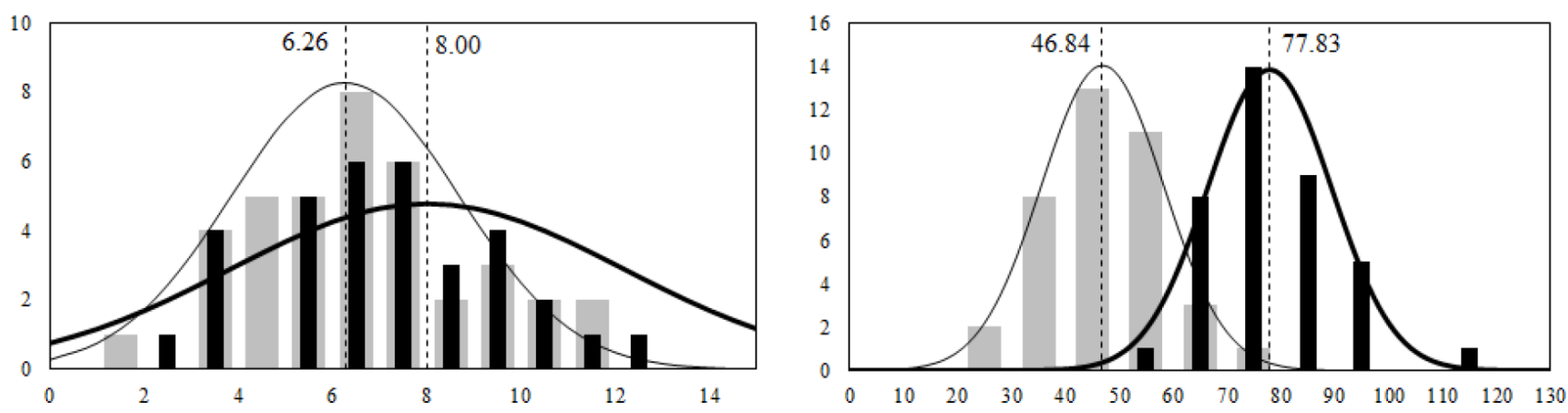

5. ábra: Acél- és szintetikus szálerősitésű betonok keresztmetszetén áthaladó szálak darabszámainak hisztogramjai és normális eloszlásfüggvénye, fekete: (B1) betonozási mód, szürke: (B2) betonozási mód

\section{KÍSÉRLETI EREDMÉNYEK}

A keresztmetszet teljes felületén, illetve különböző zónáiban található szálak darabszámának hisztogramjai és a hozzájuk tartozó normál eloszlás görbéje az 5. ábrán látható. A két különböző öntési módszer eredményeit egyazon diagramon ábrázoltuk, így eloszlásuk és középértékük szemléltethető. Minél nagyobb zónát vizsgálunk, a szórása annál kedvezőbb, így a legjobb eredményeket a teljes felületet vizsgálva kapunk.

A 4. táblázatban az analitikus és a kísérleti eredmények és azok összehasonlítása szerepel.

A keresztmetszeten áthaladó szálak darabszámát a gerenda hossza mentén is vizsgáltuk, ez a 6. ábrán van ábrázolva. 


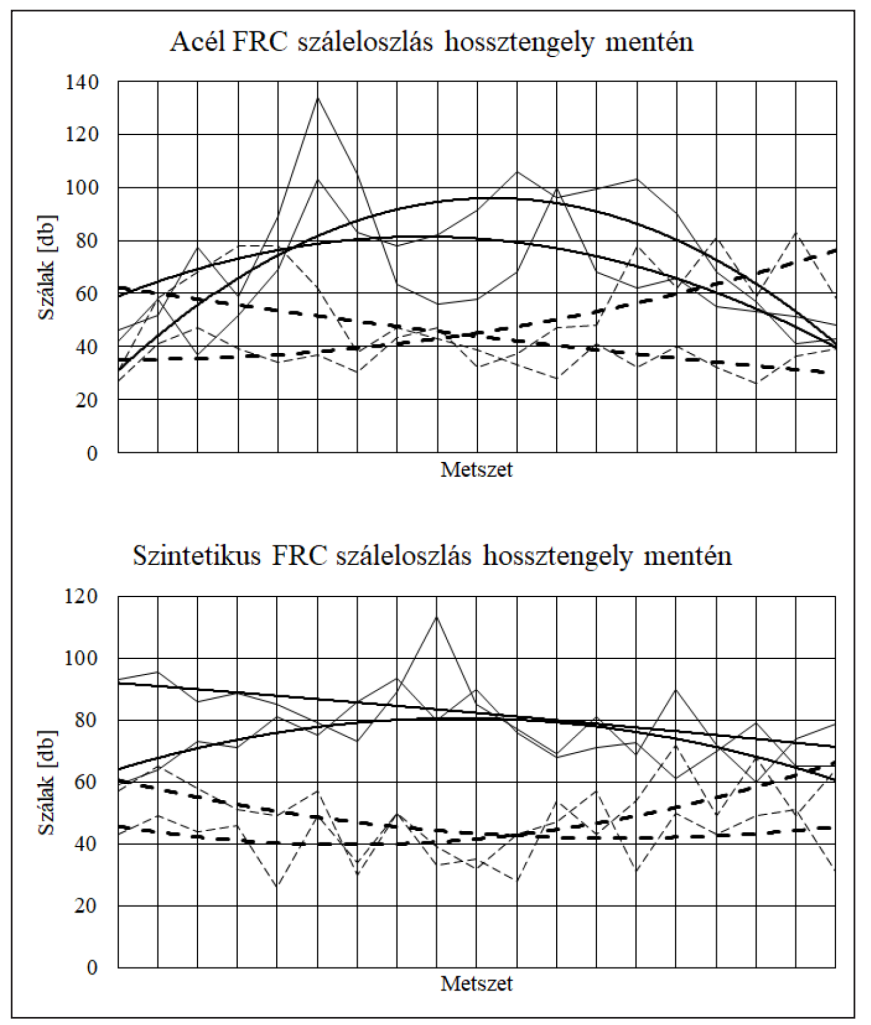

6. ábra: Acél- és szintetikus szálerősítésü beton gerenda keresztmetszetén áthaladó szálak darabszámának változása a gerenda hossztengelye mentén, folytonos vonal: vízszintes betonozás (B1), szaggatott vonal: ferde betonozás (B2)

\section{AZ EREDMÉNYEK ÉRTÉKELÉSE}

A kísérletekből egyértelmủen látszik, hogy a két betonozási mód jelentős különbséget okozott a keresztmetszeten áthaladó szálak darabszámát illetően mind acél, mind szintetikus szálak esetén. A teljes keresztmetszeten áthaladó szálak darabszáma a ferde, öntött betonozási mód (B2) esetében acélszálaknál 34\%kal, míg szintetikus szálaknál 39\%-kal tartalmazott kevesebb szálat, mint a vízszintes betonozási mód (B1) esetében. A zónákat vizsgálva ez a különbség szintén mindenhol jelentkezik. A gerenda hossztengelye mentén vizsgálva a széleken ez a különbség kisebb, míg a gerenda közepén a nagyobb (6. ábra). Mivel ez a különbség konzekvensen jelentkezett, mind a teljes keresztmetszetre, mind a zónákra nézve, így feltételezhető, hogy a betonozási mód elsősorban a szálak orientációjára volt hatással.

A magyarázatot a beton mozgásában kereshetjük. Az áramló beton mátrixban elhelyezkedő szálak a folyás irányára merőlegesen helyezkednek el (Toutanji és Bayasi, 1998; Stahli és van Mier, 2007; Stahli, Custer és van Mier, 2008). A vízszintes betonozási módszernél a zsaluzatba kerülő beton függőlegesen mozog, így ezek a szálak a gerenda hossztengelyének irányába állnak be. A vibrálás további orientációt okozhat (Soroushian és Lee, 1990; Toutanji és Bayasi, 1998; Barragán et al., 2000). Ferde betonozás esetében a beton a gerenda hossztengelyének irányába mozog, így a szálak a gerenda hossztengelyére merőleges irányba fordulnak. A gerenda szélein a végzsaluzat hatása miatt ez az orientációs hatás mérséklődik, kevésbé jelentkezik (6. ábra).

A vízszintes betonozási mód (B1) esetében szintetikus szálakból 10\%-kal több szál volt található a metszetekben, mint acélszálak esetében. Ferde betonozási mód (B2) esetében a különbség elenyésző volt, azaz acél és szintetikus szálakból is azonos mennyiségü szál volt található a metszeteken. Szintetikus szálak esetében a gerenda keresztmetszeti zónáiban az eloszlás kedvezőbb volt: vízszintes betonozási mód (B1) esetében szinte azonos volt az orientációs faktor, míg ferde betonozási mód (B2) esetében a feltételezésnek megfelelően változott, sarkokon volt a legtöbb.

A kísérleti eredmények szórása nagy (CV (relatív szórás): 14-52\%), a hisztogramok szemrevételezése alapján sok helyen aszimmetrikus vagy bimodális eloszlás mutatkozik.

A kísérleti eredmények és az analitikus modell eredményei között jelentős különbségek adódtak: acél szálerősítés és vízszintes betonozási mód esetén - $20 \%$ és $+90 \%$-os eltérések adódtak, míg ferde betonozási mód esetén az analitikus modell mindenhol felülbecsülte a szálak darabszámát. Szintetikus szálak és vízszintes betonozási mód esetén alulbecsüli (kivéve a sarok zónát), míg ferde betonozási mód esetén pedig minden esetben felülbecsüli az analitikus modell a kísérleti eredményeket. A két betonozási mód átlagát vizsgálva az analitikus módszer eredményei 20\%-os eltérésen belül vannak a sarok zónákat nem vizsgálva.

Acélszálak esetében a feltételezett eloszlás nem igazolódott: a legmagasabb szálorientáció a középső zavartalan zónában volt, míg a legalacsonyabb szálorientáció a sarkokban mindkét betonozási módszer esetében - az elmélet szerint ennek pont fordítva kellett volna lenni. Acélszálak esetében azonban figyelembe kell venni a merev szálak egymásra gyakorolt hatását, aminek alapján a középső zónákban lesz több szál, nem a szélsőkben (Kang et al., 2011; Czoboly, 2016; Juhász, 2018b). Mivel az acélszálaknál az adagolás nem mondható magasnak, ezért a szabványos $150 \times 150$ mm-es keresztmetszet így nem bizonyul megfelelően nagynak 50 mm-es acélszálak esetében.

Szintetikus szálak és vízszintes betonozási mód esetében az orientációk között nem volt nagy a különbség, hasonlóan az analitikus modell Z1 és Z2 zónáihoz. A sarkoknál használt orientációs faktor itt is felülbecsüli az értékeket. Ferde betonozási mód esetében az orientációs faktorok nagyobb mértékben eltérnek a modell értékeitől, azonban a változásuk azzal megegyező: a zavartalan zónában volt a legkisebb, majd a széleken nagyobb, végül a sarkokon a legtöbb, a növekmények azonban jóval nagyobbak voltak. A legjobb eredményeket a két betonozási mód átlagértékeinél kapjuk, a sarkoktól eltekintve az analitikus modell eredményei jól közelítik a kísérleti eredményeket.

A vizsgálatokból levonható legfontosabb megállapítások: - a betonozás módja jelentős hatással van a szálak orientációjára, a bemutatott kísérletben ez 34-40\%-os különbséget okozott a keresztmetszeten áthaladó szálak darabszámában; - a betonozás módja erösebb hatást gyakorol acélszálakra, mint a szintetikus szálakra, de mindkét száltípus esetén jelentős;

- az irodalmi eredményeknek megfelelöen a jelen kísérletben is igazolódott, hogy a beton áramlásának irányára merőlegesen helyezkednek el a szálak;

- acélszálak esetében a szálak egymásra gyakorolt hatása miatt a szálak a gerenda középső zónáiban sürübben helyezkednek el, mint a széleken;

- szintetikus szálak esetében a keresztmetszeten belüli eloszlás a feltételezettnek megfelelő volt ferde betonozási mód esetében (középső zónában a legkevesebb, majd szélsőben és sarkokon több), de az orientációs faktorok eltértek az analitikus modell eredményeitől, vízszintes betonozási mód esetében egyenletes volt, viszont az analitikus modell alulbecsülte a valós értékeket;

- nagyságrendileg a keresztmetszeteket metsző szálak darabszáma megegyezett az acél és a szintetikus szálak esetében, vízszintes betonozási módnál szintetikus szálból volt valamivel több, míg a ferde betonozási módnál elenyésző 
különbség volt az értékek között;

- a keresztmetszeti zónákban található szálak darabszáma között jelentős különbség volt acél és szintetikus szálaknál: a szintetikus szálak egyenletesebben helyezkedtek el a keresztmetszeten belül;

- az analitikus modell eredményei a teljes keresztmetszetre és a zónákra nézve is a két betonozási mód eredményei közé esnek, jó közelítéssel ezen eredmények átlagai szintetikus szálak esetében;

- a sarkokon levő szálakat mind szintetikus, mind acélszálak esetében a modell nem képes követni - igaz, ez a legkisebb zóna, a legnagyobb relatív szórással, így az eredmények tekintetében itt a legnehezebb összehasonlítani.

\section{MEGÁLLAPÍTÁSOK}

Szálerősítésű betonok törés utáni maradó szilárdságát nagyban befolyásolja a repedt keresztmetszeten áthaladó szálak darabszáma. Feltételezzük, hogy a szálak elkeveredése egyenletes, azonban sok tényező együttes hatása miatt ez a feltételezés nem teljesül maradéktalanul. A jelen cikkben a betonozás hatását vizsgáltuk acél és szintetikus szálak orientációjára. Különböző betonozási módszerrel készültek gerendák, majd a keresztmetszetek különböző zónáiban vizsgáltuk a szálak orientációit. Az eredményeket az irodalomban található numerikus modellek eredményeivel hasonlítottuk össze.

A különböző betonozási módszerrel készült gerendák szálainak orientációi között 34-40\%-os különbség adódott. Ez a különbség jelentős, az anyagvizsgálatok, illetve méretezések során ezt figyelembe kellene venni. Szabványos gerenda vizsgálatok esetén a vibrálás során a szálak a gerenda hossztengelyének irányába orientálódnak, így több szál metszi a repedési keresztmetszetet, mint egyenletes elkeveredést feltételezve. Folyós konzisztenciájú beton esetében pedig az áramlás irányára merőleges irányba orientálódnak a szálak, így ha az áramlás gerendatengely-irányú, kevesebb szál metszi a keresztmetszetet. Ezekböl adódóan a hiba többszöröződik: az anyagmodell kimérése esetén magasabb paramétereket kapunk, míg a valós szerkezeti elemnél, ha kedvezőtlen a betonozási mód kedvezőtlenebb orientáció is kialakulhat. Így a felülbecsült anyagparaméterrel készített méretezés és a valós viselkedés között nagyságrendi eltérés is adódhat.

Sorozatgyártás és nagy jelentőségű szerkezet méretezése során a szálerősítésű beton orientációjának megismerése és számításban való alkalmazása elengedhetetlen.

\section{HIVATKOZÁSOK}

Alberti, M.G., Enfedaque, A. és Gálvez, J.C. (2017), „On the prediction of the orientation factor and fibre distribution of steel and macro-synthetic fibres for fibre-reinforced concrete", Cement and Concrete Composites 77 , pp. $29-48$,

https://doi.org/10.1016/j.cemconcomp.2016.11.008

ASTM C1609 (2019), „Standard test method for flexural performance of fiber-reinforced concrete (Using beam with third-point loading)", ASTM International, West Conshohocken, PA, 2019, www.astm.org, https://doi. org/10.1520/C1609 C1609M-19

Balaguru, P.N. és Shah, S.P. (1992), „Fiber reinforced cement composites”, McGraw-Hill International Editions, Civil Engineering Series

Barragán, B.E., Gardner, D., Gettu, R. és Ferreira, L.E.T. (2000) „Study of the distribution and orientation of fibers in cast cylinders", Report for Test and Deisng Methods for Steel Fibre Reinforced Concrete, EU ContractBRPR-CT98-813.

Bernard, E.S. (2013), „Development of a 1200-mm-diameter round panel test for post-crack assessment of fiber-reinforced concrete," Advances in Civil Engineering Materials 2, 1. szám, pp. 457-471, https://doi.org/10.1520/ $\underline{\text { ACEM20120021 }}$
CNR-DT 204/2006 (2006), „Guide for the Design and Construction of Fiber-Reinforced Concrete Structures", design recommendation, Advisory Committee on Technical Recommendations for Construction, CNR, Rome

Czoboly O. (2016), „A keverési idő és a keverési mód hatása a szálak és a szálerősítésű betonok jellemzőire", Doktori disszertáció, Budapesti Müszaki és Gazdaságtudományi Egyetem.

Dupont, D. és Vandewalle, L. (2005), „Distribution of steel fibres in rectangular sections", Cement \& Concrete Composites 27, pp. 391-398, https://doi.org/10.1016/j.cemconcomp.2004.03.005

Edgington, J. és Hannant, D. J. (1972), „Steel Fibre Reinforced Concrete. The effect on fibre orientation of compaction by vibration", Materials and Structures 5, 25. szám, pp. 41-44, https://doi.org/10.1007/BF02479076

EN 14651 (2007), ,Test method for metallic fibre concrete - measuring the flexural tensile strength (limit of proportionality (LOP), residual)", European Committee for Standardization, https://doi.org/10.3403/30092475

Fekete T. (1973), „Acélszálerősítésű betonszerkezetek szilárdsági vizsgálata”, BME Közlekedésmérnöki Kar Mechanika Tanszék tanulmánya.

fib (2013), „Model Code for Concrete Structre 2010”, Wiley Erst \& Sohn

Gopalaratnam, V.S., Shah, S.P., Batson, G.B., Criswell, M.E., Ramakrishnan, V. és Wecharatana, M. (1991), „Fracture toughness of fiber reinforced concrete", ACI Materials Journal 88, 4. szám, pp. 339-353, https://doi. org/10.14359/1840

Hoy, C.W. (1998), „Mixing and mix proportioning of fibre reinforced concrete", Doktori disszertáció, Department of Civil, Structural and Environmental Engineering, University of Paisley, Scotland, 284 p.

Juhász K. P. (2014), „Szintetikus makro szálerősítésű betonok”, Diplomamunka feladat, Betontechnológia Szakirányú Továbbképzés, BME Építőanyagok és Mérnökgeológia Tanszék.

Juhász K. P. (2018a), ,Acél és szintetikus szálak orientációjának meghatározása szálerősítésü betonban”, Építés-Építészettudomány 46, 1-2. szám, pp. 221-238, https://doi.org/10.1556/096.2017.007

Juhász K. P. (2018b) „The effect of synthetic fibre reinforcement on the fracture energy of the concrete", Doktori disszertáció, Budapesti Müszaki és Gazdaságtudományi Egyetem, https://perma.cc/4JMY-HN5C

Juhász K.P. (2019), „Analytical model for rigid (steel) and flexible (synthetic) fibre mixing in concrete", IOP Conference Series: Materials Science and Engineering 596, https://doi.org/10.1088/1757-899X/596/1/012003

Kameswara Rao, C.V.S. (1979), „Effectiveness of random fibres in composites", Cement and Concrete Research 9, pp. 685-693, https://doi. org/10.1016/0008-8846(79)90063-2

Kang, S.T., Lee, B.Y., Kim, J-K., Kim, Y.Y. (2011), „The effect of fibre distribution characteristics on the flexural strength of steel fibre-reinforced ultra high strength concrete", Construction and Building Materials 25, 5. szám, pp. 2450-2457, https://doi.org/10.1016/j.conbuildmat.2010.11.057

Kooiman, A.G. (2000), „Modelling steel fibre reinforced concrete for structural design", Doktori disszertáció, Technical University of Delft (The Netherlands), pp. 87-106.

Krenchel, H. (1975), „Fibre spacing and specific fibre surface”, A. Neville, (ed.) Fibre reinforced cement and concrete, London: The Construction Press, pp. 67-75.

Lee, S.C., Cho, J.Y., és Vecchio, F. J. (2011), „Diverse Embedment Model for Steel Fiber-Reinforced Concrete in Tension: Model Development", ACI Materials Journal 108, 5. szám, pp. 516-525, https://doi. org $/ 10.14359 / 51683261$

Naaman, A. E. (1972), „A statistical theory of strength for fiber reinforced concrete", Doktori disszertáció, Massachusetts Institute of Technology.

Ng, T.S., Foster, S.J. és Htut T.N.S. (2012), „Fracture of Steel Fibre Reinforced Concrete - the Unified Variable Engagement Model", UNICIV Report R-460, School of Civil and Environmental Engineering, The University of New South Wales.

Oh, B.H., Kim, J.C. és Choi, Y.C. (2007), „Fracture behavior of concrete members reinforced with structural synthetic fibers", Engineering Fracture Mechanics 74, pp. 243-257, https://doi.org/10.1016/j. engfracmech.2006.01.032

Österreichusche Vereinigung für Beton- und Bautechnik (2008), „Richtlinie Faserbeton", Vienna.

Palotás L. (1975) „Siome-rendszerű acélszál-erősítésű betoncsövek”, BME Építőanyagok Tanszék tanulmánya.

Romualdi, J.P. és Mandel, J.A. (1964), ,Tensile strength of concrete affected by uniformly distributed and closely spaced short lengths of wire reinforcement", Journal of the American Concrete Institute 61, 6. szám, pp. 657-671, https://doi.org/10.14359/7801

Sarmiento, E. V., Zirgulis, G., Sandbakk, S., Geiker, M. R. és Kanstad, T. (2012), „Influence of concrete flow on fibre distribution, orientation and mechanical properties of fibre reinforced concrete", J. Barros (ed) BEFIB2012 - Fibre reinforced concrete

Stahli, P. és van Mier, J.G.M. (2007), „Effect of Manufacturing Methods on Tensile Properties of Fibre Concrete", Proceedings of Fracture Mechanics for Concrete and Concrete Structures (FraMCos)6, Catania, Italy.

Stahli, P., Custer, R. és van Mier, J.G.M., (2008), „On flow properties, fibre distribution, fibre orientation and flexural behaviour of FRC", Materials and Structures 41, 1. szám, pp. 189-196, https://doi.org/10.1617/ $\underline{\mathrm{s} 11527-007-9229-\mathrm{x}}$ 
Stroeven, P. (1978), „Morphometry of fiber reinforced cementitious materials”, Materials and Structures 11, 61. szám, pp. 31-37, https://doi.org/10.1007/ BF02478701

Stroeven, P. (1979), „Morphometry of Fibre Reinforced Cementitious Materials, Part II: Inhomogenity, segregation and anisometry of partially oriented fibre structures", Materials and Structures 12, 67. szám, pp. 9-20, https://doi.org/10.1007/BF02473994

Stroeven, P. (1991), ,Effectiveness of steel wire reinforcement in a boundary layer of concrete”, Acta Stereol 10, 1. szám, pp.113-22.

Stroeven, P. (1999), „Steel fibre reinforcement at boundaries in concrete elements", Proceedings of the Third International Workshop on High Performance Fiber Reinforced Cement Composites (HPFRCC3), Mainz (Germany), pp. 413-421.

Soroushian, P. és Lee, C. (1990), „Distribution and orientation of fibers in steel fiber reinforced concrete", ACI Mater Journal 87, 5. szám, pp. 433-439, https://doi.org/10.14359/1803

Szabó I. (1976), „Acélhaj beton”, Müszaki Könyvkiadó, Budapest.

Toutanji, H. és Bayasi, Z. (1998), „Effects of Manufacturing Techniques on the Flexural Behavior of Steel Fiber-Reinforced Concrete", Cement and Concrete Research 28, 1. szám, pp. 115-124, https://doi.org/10.1016/ S0008-8846(97)00213-5

Vandewalle, L. et al. (2003), „RILEM TC 162-TDF: Test and design methods for steel fibre reinforced concrete $-\sigma-\varepsilon$ design method", Materials and Structures 36, 8. szám, pp. 560-567, https://doi. org/10.1617/14007
Zerbino, R., Tobes J. M., Bossio M. E. és Giaccio G. (2012), „On the orientation of fibres in structural members fabricated with self compacting fibre reinforced concrete", Cement \& Concrete Composites 34, pp. 191-200, https://doi.org/10.1016/j.cemconcomp.2011.09.005

Dr. Juhász Károly Péter (1980), okleveles építészmérnök, tartószerkezeti tervező, adjunktus, laborvezető, Budapesti Müszaki és Gazdaságtudományi Egyetem, Szilárdságtani és Tartószerkezeti Tanszék. Fő kutatási területe a szálerősítésű betonok anyagvizsgálata és modellezése. Tulajdonos és vezető mérnök a JKP Static Kft-nél. Tagja a fib 2.4.2 munkacsoportnak.

Effect of the pouring technique on the orientation of steel and synthetic macro fibers in fiber reinforced concrete Karoly Peter Juhasz

Fibre reinforced concrete is a short fibre composite material, with properties significantly dependent on the orientation of the mixed fibres. As a starting point the fibres are assumed to be uniformly distributed and have a uniform orientation, but in reality a non-uniform distribution occurs due to various effects. Deviation from the uniform orientation could have a significant effect on the material parameters, both favourable and unfavourable. In this paper the mixing models of the literature are compared to test results, and the effects of the formwork, the casting and compaction methods on the orientation of steel and synthetic macro fibres are investigated. 